\title{
The Synthesis of Glycosaminoglycans by Cultures of Corneal Stromal Cells from Patients with Keratoconus
}

\author{
Beatrice Y. J. T. Yue and Jules L. Baum, Department of Ophthalmology, New \\ England Medical Center Hospital and Tufts University School of \\ Medicine, Boston, Massachusetts 02111 \\ Jeremiah E. Silbert, Connective Tissue-Aging Research Laboratory, Veterans \\ Administration Outpatient Clinic, Boston, Massachusetts 02108
}

\begin{abstract}
A B S T RACT Keratoconus is a disease that results in thinning and ectasia of the central cornea. Cultures of corneal stromal cells from patients with keratoconus were established and the synthesis of glycosaminoglycans compared with the synthesis of glycosaminoglycans by normal human corneal stromal cells in culture.
\end{abstract}

Keratoconus and normal control cell cultures were incubated with sodium $\left[{ }^{35} \mathrm{~S}\right]$ sulfate and $\left[{ }^{3} \mathrm{H}\right] \mathrm{glu}$ cosamine for $4 \mathrm{~h}$. After incubation, the labeled glycosaminoglycans were isolated from the medium fractions and cells. Keratoconus and normal control cultures synthesized similar amounts of sulfated glycosaminoglycans independent of the age of donors and(or) the number of subcultures. In contrast to normal control cultures, most of the newly synthesized glycosaminoglycans produced by keratoconus cells were found in the growth medium and much less were in the cell layer.

Treatment with glycosaminoglycan-degrading enzymes followed by paper chromatography showed that keratoconus cells, as normal control cells, produced hyaluronic acid and various sulfated glycosaminoglycans. The production of cell layer-related heparan sulfate was markedly reduced in keratoconus cultures. Because heparan sulfate has been shown to be associated with cell surfaces, the decreased heparan sulfate content could reflect changes at this location.

\section{INTRODUCTION}

Keratoconus is a disease that gradually thins and distorts the central cornea and usually leads to visual

Portions of this work were presented at the Annual Meeting of the Association for Research in Vision and Ophthalmology, Sarasota, Fla., 2 May 1978.

Received for publication 25 September 1.978 and in revised form 13 November 1978. impairment. Histological and structural changes (1-4) in the cornea include degeneration of basal epithelial cells, fragmentation of the basement membrane, fibrillation of Bowman's membrane, reduction of the stromal lamellae and their partial replacement by an irregularly arranged connective tissue. The pathogenesis is unknown.

Relatively little biochemical information is available concerning this disease process. A preliminary report (5) has shown that the total amount of glycosaminoglycans (expressed as percentage of hexosamine per dry weight tissue) was $1.4 \%$ both in normal human and keratoconus corneas. No significant differences were observed in elution patterns from. an epichlorohydrin triethanolamine column. A subsequent study (6) described a slight increase in the glucosamine:galactosamine ratio from corneas with keratoconus and suggested that the keratan sulfate content was increased, whereas the chondroitin sulfate fraction was decreased. A reduction in the total collagen content (7) and an abnormality in the collagen cross-linking (8) have also been reported. Except for this last study, none of the changes were of sufficient degree to provide assurance that direct measurement of the corneal tissue was a fruitful approach to study this disease.

The use of tissue cultures of skin fibroblasts for investigation of the systemic mucopolysaccharidoses has produced significant advances in the understanding of these conditions (9). Similar methods with corneal cell cultures have been employed in the study of one corneal disease, macular corneal dystrophy. There was a suggestion of glycosaminoglycan changes by histochemistry (10) but no demonstrable chemical abnormalities (11).

We have previously characterized the glycosaminoglycans produced by cultures of stromal cells from normal human corneas (12). With that as background, we undertook this study to investigate the synthesis of glycosaminoglycans by cultures of corneal stromal cells 
from patients with keratoconus. In contrast to the reported absence of glycosaminoglycan changes from macular dystrophic corneal cells, we have observed significant differences in heparan sulfate production from cultured keratoconus corneal cells when compared to normal controls.

\section{METHODS}

Cell cultures. Normal human corneas were obtained from the New England Eye Bank, Boston, Mass. Corneal buttons from three patients with keratoconus (a 24-yr-old male with keratoconus for $10 \mathrm{yr}$; a 44-yr-old male with keratoconus for $15 \mathrm{yr}$; and a 48-yr-old female with keratoconus for $4 \mathrm{yr}$ ) were placed into a McCarey-Kaufman (13) medium immediately after penetrating keratoplasty and sent to our laboratory. All three had bilateral disease suggesting an underlying metabolic defect.

The middle portion of the stromal layer was obtained from corneas as described (14). This entailed stripping off Descemet's membrane with the attached endothelium and then removing the superficial epithelial stromal layer. The pure explant was cultured as described $(15,16)$ in $75-\mathrm{ml}$ Falcon flasks (Falcon Plastics, Div. of BioQuest, Oxnard, Calif.) at $37^{\circ} \mathrm{C}$ under $5 \% \quad \mathrm{CO}_{2}, 95 \%$ air. The culture medium was changed twice weekly.

When cells in culture had reached confluence (3-4 wk), the culture flasks were treated with EDTA (0.02\%) and trypsin $(0.05 \%$, Grand Island Biological Co., Grand Island, N. Y.) for 5 min and cells subcultured employing the same culture procedure. Glycosaminoglycan studies were performed generally between the second and fourth subcultures.

For convenience, cultures of stromal cells grown from agematched normal human corneas will henceforth be referred to as normal control cells or normal control cultures; the cultures of corneal stromal cells from keratoconus patients will be called keratoconus cells or keratoconus cell cultures.

Production of glycosaminoglycans. In a typical experiment, two flasks of confluent corneal cultures were incubated with Eagle's minimal essential medium containing $100 \mu \mathrm{Ci} /$ $\mathrm{ml}$ of sodium $\left[{ }^{35} \mathrm{~S}\right]$ sulfate and $40 \mu \mathrm{Ci} / \mathrm{ml}$ of $\left[{ }^{3} \mathrm{H}\right]$ glucosamine for $4 \mathrm{~h}$. After incubation, the medium was removed from all flasks and combined as a medium fraction. The cultures were washed six times with $8 \mathrm{ml}$ of Dulbecco's phosphate-buffered saline and the cells harvested with $0.25 \%$ trypsin. Cell numbers in some samples were determined with a hemocytometer. The cells were then broken with a Polytron homogenizer (Brinkmann Instruments, Inc., Westbury, N. Y.). This preparation contained both intracellular and pericellular material and is referred to as the cell layer fraction.

Identification of glycosaminoglycans. Samples of the medium and cell layer fractions were chromatographed on a column of Sephadex G-50 (Pharmacia Fine Chemicals, Div. of Pharmacia Inc., Piscataway, N. J.) as described (16) to separate the newly synthesized radioactive glycosaminoglycans. The total radioactivity associated with the labeled products was used to estimate the amount of glycosaminoglycan produced per milligram of protein as an index of glycosaminoglycan synthesis. The protein in the cell layer of corneal cultures was assayed with fluorescamine (17) using bovine serum albumin as standard. The specific activity of the $\left.{ }^{35} \mathrm{~S}\right]$ sulfate in the incubation medium was determined from the amount of $\left[{ }^{35} \mathrm{~S}\right]-$ sulfate added to the medium and the amount of inorganic sulfate present.

Sulfated glycosaminoglycans produced by normal and keratoconus stromal cultures were characterized by sequen- tial treatment with chondroitinase $\mathrm{AC}$ and chondroitinase ABC (Miles Laboratories Inc., Miles Research Products Elkhart, Ind.) as described (16). Chondroitinase AC only degrades hyaluronic acid, chondroitin 4-sulfate, and chondroitin 6sulfate. Chondroitinase ABC degrades these plus dermatan sulfate. Neither enzyme has activity on heparan sulfate, heparin, or keratan sulfate. Carrier standard chondroitin 4sulfate (Miles Laboratories Inc.) was added in each enzyme incubation to confirm the enzyme activities. After enzyme digestions, each reaction mixture was chromatographed on a column $(1 \times 20 \mathrm{~cm})$ of Sephadex G-50 with $0.1 \mathrm{M} \mathrm{LiCl}$ solution, and radioactivity was determined for each fraction. Degradation products of the carrier standard were located by the carbazole assay (18). The amount of labeled material appearing in the included fractions from the column represented the degraded glycosaminoglycan products; the amount appearing in the excluded fractions represented the intact glycosaminoglycans resistant to the specific enzyme (16).

For some samples, the intact glycosaminoglycans recovered after chondroitinase ABC digestion were further treated with crude heparinase prepared from Flavobacterium heparinum as described (16). This enzyme can degrade all types of glycosaminoglycans except keratan sulfate.

Disaccharide products of chondroitinase $\mathrm{ABC}$ digestion were identified as described (19) by chromatography on Whatman No. 1 paper (Whatman, Inc., Clifton, N. J.) together with disaccharide standards $\Delta \mathrm{Di}-4 \mathrm{~S}, \Delta \mathrm{Di}-6 \mathrm{~S}, \Delta \mathrm{Di}-0 \mathrm{~S}$, and unsaturated hyalobiuronic acid. ${ }^{1}$ Chromatograms were developed for $18 \mathrm{~h}$ in butan-1-ol:acetic acid:1.0 $\mathrm{M}$ ammonium hydroxide (2:3:1, by volume). After chromatography, the carrier disaccharides were visualized with UV light and the chromatograms were then cut into $1-\mathrm{cm}$ strips which were then assayed for radioactivity. The hyaluronic acid content was determined from the amount of $\left[{ }^{3} \mathrm{H}\right]$ disaccharides co-chromatographing with unsaturated hyalobiuronic acid.

\section{RESULTS}

Keratoconus cells (Fig. 1A) and normal control cells (Fig. 1B) looked similar under phase-contrast microscopy, displaying the long, thin, spindle-shaped morphological characteristics of fibroblasts. The growth rate and pattern of keratoconus and normal control cells in culture were similar, although it was our impression that keratoconus cells could be subcultured only 10-15 times, whereas normal control cells could be maintained for a longer period (20-30 subcultures). This, however, was not examined rigorously. The cell densities and the cell protein contents of cultures are shown in Table I. These represented duplicate flasks that were pooled before assay. There were no apparent differences in cell number or protein content between normal and keratoconus cells.

The production of sulfated glycosaminoglycans by

\footnotetext{
${ }^{1}$ Nomenclature used in this paper: $\Delta \mathrm{Di}-4 \mathrm{~S}, 2$-acetamido2-deoxy-3-0-( $\beta$-D-gluc-4-enepyranosyluronic acid)-4-0-sulfoD-galactose; $\Delta$ Di-6S, 2-acetamido-2-deoxy-3-0-( $\beta$-D-gluc-4enepyranosyluronic acid)-6-0-sulfo-D-galactose; $\Delta \mathrm{Di}-0 \mathrm{~S}, 2$ acetamido - 2 - deoxy - 3 - 0 - ( $\beta$ - D - gluc - 4 - enepyranosyluronic acid)-D-galactose; unsaturated hyalobiuronic acid; 2 acetamido-2-deoxy-3-0-( $\beta$-D-gluc-4-enepyranosyluronic acid)-D-glucose.
} 


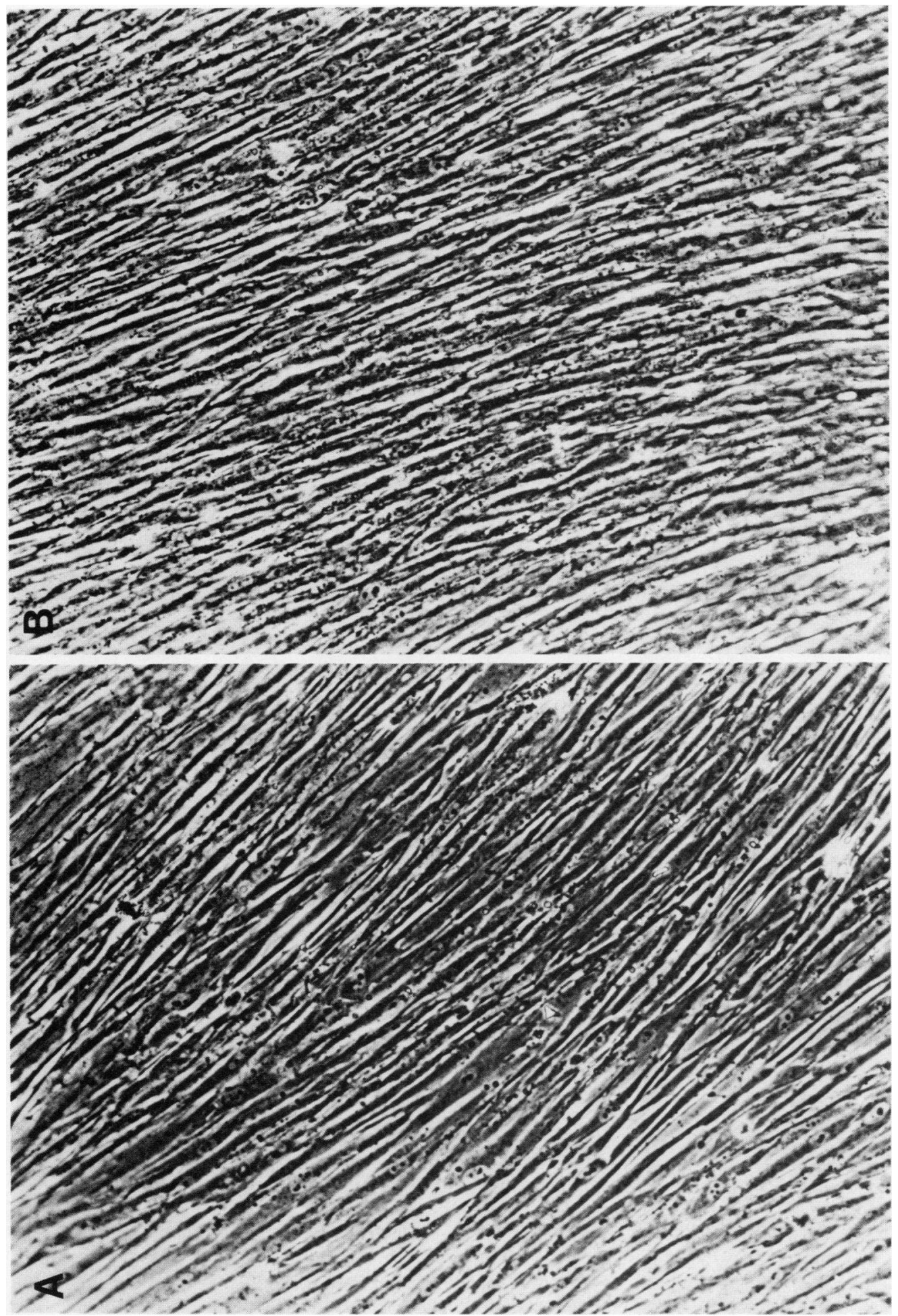


TABLE I

Cell Number and Protein Content

\begin{tabular}{cccccc}
\hline Cells & $\begin{array}{c}\text { Age of } \\
\text { donor }\end{array}$ & $\begin{array}{c}\text { No. of } \\
\text { subcul- } \\
\text { tures }\end{array}$ & $\begin{array}{c}\text { Cell } \\
\text { number }\end{array}$ & $\begin{array}{c}\text { Total } \\
\text { cell } \\
\text { protein }\end{array}$ & $\begin{array}{c}\text { No. of cells/ } \\
\text { cell } \\
\text { protein }\end{array}$ \\
\hline \multirow{3}{*}{ Normal } & $17 \mathrm{mo}$ & 3 & $4.1 \times 10^{6}$ & 2.1 & $2.0 \times 10^{6}$ \\
& & 4 & - $^{*}$ & 1.7 & - \\
& $16 \mathrm{yr}$ & 0 & $2.7 \times 10^{6}$ & 1.7 & $1.6 \times 10^{6}$ \\
& $50 \mathrm{yr}$ & 2 & $2.5 \times 10^{6}$ & 1.2 & $2.1 \times 10^{6}$ \\
& & 3 & $3.0 \times 10^{6}$ & 1.6 & $1.9 \times 10^{6}$ \\
& $60 \mathrm{yr}$ & 2 & $3.9 \times 10^{6}$ & 2.3 & $1.7 \times 10^{6}$ \\
Kerato- & $24 \mathrm{yr}$ & 3 & $-{ }^{*}$ & 2.4 & - \\
conus & $44 \mathrm{yr}$ & 2 & $4.6 \times 10^{6}$ & 2.9 & $1.6 \times 10^{6}$ \\
& & 3 & $5.7 \times 10^{6}$ & 2.6 & $2.2 \times 10^{6}$ \\
& $48 \mathrm{yr}$ & 3 & $4.5 \times 10^{6}$ & 2.3 & $2.0 \times 10^{6}$ \\
& & 4 & $3.6 \times 10^{6}$ & 2.1 & $1.7 \times 10^{6}$ \\
\hline
\end{tabular}

* These were not counted but looked similar to the other flasks in cell density.

confluent cultures of normal control and keratoconus cells based on the $\left[{ }^{35} \mathrm{~S}\right]$ sulfate incorporation is shown in Table II. Generally, with normal control cells, more labeled material was present within the cell layer than in the growth medium. However, this was reversed in keratoconus cultures, with most of the newly synthe- sized products present in the growth medium and much less in the cell layer. The total amount of sulfated glycosaminoglycans produced by normal and keratoconus cell cultures based on the cell protein appeared to be similar, independent of the age of donors and(or) the number of subcultures.

Tables III and IV depict the amounts of the various sulfated glycosaminoglycans isolated from the medium and the cell layer fractions of normal and keratoconus cell cultures. In agreement with our previous report (12), no significant differences were observed by variations in age of donors and(or) number of subcultures. Chondroitin 6-sulfate always made up the largest portion of the sulfated glycosaminoglycans. Chondroitin 4-sulfate and dermatan sulfate were present in smaller amounts; chondroitinase ABC-resistant material accounting for the remainder. We have previously shown $(12,16)$ that in normal corneal stromal cell cultures, no heparin is produced and keratan sulfate is present only in minimal amounts. Therefore, the chondroitinase ABC-resistant material is essentially heparan sulfate. Likewise, in keratoconus cells, the chondroitinase ABC-resistant material was degraded by crude heparinase indicating that this represented heparan sulfate and not keratan sulfate.

The relative amounts of the various sulfated glycosaminoglycans in the medium fraction of normal and

TABLE II

Incorporation of ${ }^{35}$ S $]$ Sulfate into Sulfated Glycosaminoglycans

\begin{tabular}{|c|c|c|c|c|c|c|}
\hline \multirow[b]{2}{*}{ Cells } & \multirow{2}{*}{$\begin{array}{l}\text { Age of } \\
\text { donor }\end{array}$} & \multirow{2}{*}{$\begin{array}{c}\text { No. of } \\
\text { subculture }\end{array}$} & \multicolumn{2}{|c|}{$\begin{array}{l}\text { Total }\left[{ }^{35 S}\right] \text { sulfate } \\
\text { incorporated }\end{array}$} & \multirow{2}{*}{$\begin{array}{l}\text { Total }\left[^{35} \text { S]glycos- }\right. \\
\text { aminoglycans } \\
\text { produced }\end{array}$} & \multirow{2}{*}{$\begin{array}{l}\text { Glycosaminoglycans } \\
\text { produced/ } \\
\text { cell protein }\end{array}$} \\
\hline & & & Cell layer & Medium & & \\
\hline & & & \multicolumn{2}{|c|}{$d p m \times 10^{-4}$} & ng & $m g$ \\
\hline \multirow[t]{6}{*}{ Normal } & $17 \mathrm{mo}$ & 3 & 13.6 & 10.5 & 150 & 71 \\
\hline & & 4 & 9.3 & 9.3 & 115 & 69 \\
\hline & $16 \mathrm{yr}$ & 0 & $40.0^{*}$ & 11.5 & 84 & 50 \\
\hline & $50 \mathrm{yr}$ & 2 & 9.1 & 3.0 & 75 & 65 \\
\hline & & 3 & 15.0 & 6.3 & 132 & 83 \\
\hline & $60 \mathrm{yr}$ & 2 & $63.0^{*}$ & 26.9 & 159 & 65 \\
\hline \multirow[t]{5}{*}{ Keratoconus } & $24 \mathrm{yr}$ & 3 & 2.0 & 21.3 & 144 & 60 \\
\hline & $44 \mathrm{yr}$ & 2 & 5.4 & 14.5 & 123 & 43 \\
\hline & & 3 & 4.3 & 20.3 & 153 & 58 \\
\hline & $48 \mathrm{yr}$ & 3 & 4.2 & 17.3 & 133 & 58 \\
\hline & & 4 & 6.2 & 15.2 & 133 & 64 \\
\hline
\end{tabular}

Cultures were labeled with medium containing $2.2 \times 10^{8} \mathrm{dpm} / \mathrm{ml}$ of sodium $\left.{ }^{35} \mathrm{~S}\right] \mathrm{sulfate}$ for $4 \mathrm{~h}$. The amount of sulfated glycosaminoglycans produced was estimated from the specific activity $(0.80 \mathrm{dpm} / \mathrm{pmol})$ of $\left.{ }^{35} \mathrm{~S}\right]$ sulfate by assuming that one sulfate group is present in each disaccharide unit of glycosaminoglycans. Thus, the nanogram amounts are approximate, but are useful for the purposes of comparison. The amount of glycosaminoglycans produced per milligram of cell protein was calculated from Table I. Each line of results represents an independent experiment consisting of two pooled cultures.

* Data from Table I, reference 12 . The specific activity of $\left.{ }^{35} \mathrm{~S}\right]$ sulfate was $3.1 \mathrm{dpm} / \mathrm{pmol}$. 
TABLE III

Relative Percentage of Sulfated Glycosaminoglycans in the Medium Fraction of Corneal Cultures

\begin{tabular}{|c|c|c|c|c|c|c|}
\hline Cells & $\begin{array}{l}\text { Age of } \\
\text { donor }\end{array}$ & $\begin{array}{l}\text { No. of sub- } \\
\text { cultures }\end{array}$ & $\begin{array}{c}\text { Chondroitin } \\
\text { 6-sulfate }\end{array}$ & $\begin{array}{c}\text { Chondroitin } \\
\text { 4-sulfate }\end{array}$ & $\begin{array}{l}\text { Dermatan } \\
\text { sulfate }\end{array}$ & $\begin{array}{l}\text { Heparan } \\
\text { sulfate* }\end{array}$ \\
\hline \multirow[t]{6}{*}{ Normal } & \multirow[t]{2}{*}{$17 \mathrm{mo}$} & 3 & 59 & 26 & 9 & 6 \\
\hline & & 4 & 60 & 24 & 12 & 4 \\
\hline & $16 \mathrm{yr}$ & 0 & 56 & 20 & 20 & 4 \\
\hline & \multirow[t]{2}{*}{$50 \mathrm{yr}$} & 2 & 67 & 18 & 11 & 4 \\
\hline & & 3 & 62 & 25 & 8 & 5 \\
\hline & $60 \mathrm{yr}$ & 2 & 66 & 16 & 12 & 6 \\
\hline \multirow[t]{5}{*}{ Keratoconus } & $24 \mathrm{yr}$ & 3 & 58 & 21 & 19 & 2 \\
\hline & \multirow[t]{2}{*}{$44 \mathrm{yr}$} & 2 & 60 & 23 & 15 & 4 \\
\hline & & 3 & 54 & 24 & 18 & 4 \\
\hline & \multirow[t]{2}{*}{$48 \mathrm{yr}$} & 3 & 67 & 21 & 11 & 1 \\
\hline & & 4 & 56 & 24 & 17 & 3 \\
\hline
\end{tabular}

* As described in the text, heparan sulfate was the predominant glycosaminoglycan representing the material resistant to chondroitinase $\mathrm{ABC}$.

keratoconus cultures were similar, although there was a suggestion of less heparan sulfate in the medium fraction of the keratoconus cultures. In the cell layer, keratoconus cells contained a higher proportion of chondroitin 6- and 4-sulfates and significantly less heparan sulfate.

To evaluate the production of heparan sulfate further, the amounts of this chondroitinase ABC-resistant material present in the cell layer and the medium fractions were calculated from Tables II-IV. The results are shown in Table V. It can readily be seen that in normal control cultures, most of the heparan sulfate produced was associated with the cell layer. Cell cultures derived from keratoconus tissues, however, con- tained markedly reduced amounts of cell layer-related heparan sulfate that was in turn reflected in the total production and the distribution of heparan sulfate.

The hyaluronic acid content as determined by paper chromatography is shown in Table VI. Hyaluronic acid generally represented one-fourth to one-third of the total glycosaminoglycans. The amount of hyaluronic acid produced by normal and keratoconus cells was similar regardless of the age of donors.

\section{DISCUSSION}

This study demonstrates that confluent cultures of corneal stromal cells derived from patients with

TABLE IV

Relative Percentage of Sulfated Glycosaminoglycans in the Cell Layer of Corneal Cultures

\begin{tabular}{|c|c|c|c|c|c|c|}
\hline Cells & $\begin{array}{l}\text { Age of } \\
\text { donor }\end{array}$ & $\begin{array}{l}\text { No. of sub- } \\
\text { cultures }\end{array}$ & $\begin{array}{c}\text { Chondroitin } \\
\text { 6-sulfate }\end{array}$ & $\begin{array}{c}\text { Chondroitin } \\
\text { 4-sulfate }\end{array}$ & $\begin{array}{c}\text { Dermatan } \\
\text { sulfate }\end{array}$ & $\begin{array}{l}\text { Heparan } \\
\text { sulfate* }\end{array}$ \\
\hline \multirow[t]{6}{*}{ Normal } & $17 \mathrm{mo}$ & 3 & 56 & 19 & 13 & 12 \\
\hline & & 4 & 50 & 21 & 15 & 14 \\
\hline & $16 \mathrm{yr}$ & 0 & 54 & 18 & 10 & 18 \\
\hline & $50 \mathrm{yr}$ & 2 & 57 & 21 & 11 & 11 \\
\hline & & 3 & 44 & 24 & 17 & 15 \\
\hline & $60 \mathrm{yr}$ & 2 & 48 & 13 & 22 & 17 \\
\hline \multirow[t]{5}{*}{ Keratoconus } & $24 \mathrm{yr}$ & 3 & 55 & 27 & 14 & 4 \\
\hline & $44 \mathrm{yr}$ & 2 & 60 & 26 & 13 & 1 \\
\hline & & 3 & 63 & 19 & 16 & 2 \\
\hline & $48 \mathrm{yr}$ & 3 & 53 & 30 & 15 & 2 \\
\hline & & 4 & 60 & 26 & 12 & 2 \\
\hline
\end{tabular}

* As described in the text, heparan sulfate was the predominant glycosaminoglycan representing the material recovered after chondroitinase ABC digestion. 
TABLE V

Production of Heparan Sulfate in Corneal Cell Cultures

\begin{tabular}{|c|c|c|c|c|c|}
\hline \multirow[b]{2}{*}{ Cells } & \multirow{2}{*}{$\begin{array}{l}\text { Age of } \\
\text { donor }\end{array}$} & \multirow{2}{*}{$\begin{array}{l}\text { No. of } \\
\text { sub- } \\
\text { cultures }\end{array}$} & \multicolumn{2}{|c|}{$\begin{array}{c}\text { Chondroitinase } \\
\text { ABC-resistant } \\
\text { material/cell } \\
\text { protein }\end{array}$} & \multirow{2}{*}{$\begin{array}{c}\text { Total pro- } \\
\text { duction }\end{array}$} \\
\hline & & & layer & Medium & \\
\hline & & & & & $\begin{array}{c}\text { ng/mg of cell } \\
\text { protein }\end{array}$ \\
\hline \multirow[t]{6}{*}{ Normal } & $17 \mathrm{mo}$ & 3 & 4.8 & 1.9 & 6.7 \\
\hline & & 4 & 4.8 & 1.4 & 6.2 \\
\hline & $16 \mathrm{yr}$ & 0 & 6.9 & 0.4 & 8.3 \\
\hline & $50 \mathrm{yr}$ & 2 & 5.4 & 0.6 & 6.0 \\
\hline & & 3 & 8.7 & 1.2 & 9.9 \\
\hline & $60 \mathrm{yr}$ & 2 & 7.8 & 1.2 & 9.0 \\
\hline \multirow{5}{*}{$\begin{array}{l}\text { Kerato- } \\
\text { conus }\end{array}$} & $24 \mathrm{yr}$ & 3 & 0.2 & 2.2 & 2.4 \\
\hline & $44 \mathrm{yr}$ & 2 & 0.1 & 1.3 & 1.4 \\
\hline & & 3 & 0.3 & 1.7 & 2.0 \\
\hline & $48 \mathrm{yr}$ & 3 & 0.2 & 0.5 & 0.7 \\
\hline & & 4 & 0.4 & 1.4 & 1.8 \\
\hline
\end{tabular}

keratoconus, as in normal control cultures, synthesize hyaluronic acid and various sulfated glycosaminoglycans. The total production of sulfated glycosaminoglycans and the hyaluronic acid are comparable.

An abnormality in the distribution of glycosaminoglycans is found in keratoconus cell cultures. Normal human stromal cells, when incubated with $\left.{ }^{35} \mathrm{~S}\right]$ sulfate for $4 \mathrm{~h}$, synthesize ${ }^{35}$ S ]glycosaminoglycans and distribute a large proportion of the products within the cell layer. Keratoconus cells, in contrast, have most of the newly synthesized material in the growth medium and display a much decreased amount of glycosaminoglycans within the cell layer.

Further characterization of the glycosaminoglycans indicated that keratoconus cells contain significantly

TABLE VI

Hyaluronic Acid Content

\begin{tabular}{cccc}
\hline \multirow{2}{*}{ Cell type } & $\begin{array}{c}\text { Age of } \\
\text { donor }\end{array}$ & $\begin{array}{c}\text { Hyaluronic acid as } \\
\text { percentage of total } \\
\text { glycosaminoglycans }\end{array}$ \\
\cline { 3 - 4 } Normal human stroma & $17 \mathrm{mo}$ & $22 \pm 4^{*}$ & $21 \pm 3$ \\
& $16 \mathrm{yr}$ & $27 \pm 3$ & $28 \pm 2$ \\
& $50 \mathrm{yr}$ & $18 \pm 2$ & $21 \pm 4$ \\
Keratoconus & $60 \mathrm{yr}$ & $38 \pm 1$ & $30 \pm 2$ \\
& $24 \mathrm{yr}$ & $29 \pm 3$ & $26 \pm 3$ \\
& $44 \mathrm{yr}$ & $36 \pm 4$ & $47 \pm 4$ \\
& $48 \mathrm{yr}$ & $24 \pm 5$ & $23 \pm 4$ \\
\hline
\end{tabular}

* Mean \pm SD. less heparan sulfate in the cell layer than do normal control cells. Heparan sulfate has been shown to be associated with cell surfaces (20-22) suggesting that the lower production by keratoconus cells may reflect some changes at the cell surface.

It is possible that the decreased glycosaminoglycan content in the cell layer of keratoconus cultures may be an expression of the abnormal matrix imposed by the decreased production of heparan sulfate. It is also possible that other materials such as collagen or structural glycoproteins in the cell layer are not retaining the glycosaminoglycans in the keratoconus cells. We have examined the collagen synthesized by keratoconus cultures and demonstrated that keratoconus cells and normal control cells synthesize similar amounts of collagen and both contain type I collagen and A, B chains. However, the relative amount of A, B chains synthesized was noted to be significantly increased in keratoconus cultures. ${ }^{2}$ It is known that in cornea, glycosaminoglycans interact closely with collagen. The abnormal collagen synthesis by keratoconus cells could possibly be coupled with variations in the metabolism of glycosaminoglycans. Alternatively, this may involve modifications in the secretion mechanism which result in the releasing of most of the glycosaminoglycans into the growth medium by keratoconus cells. At present it is not clear what is really involved in the disease, partly because of the limitations in relating observations in the corneal cultures to the pathology of keratoconus in vivo. It has been shown $(12,16,23)$ that corneal cultures produce very little keratan sulfate. Therefore, the pattern of sulfated glycosaminoglycan synthesized is considerably different from that seen in corneal tissues. However, it is still of interest that keratoconus is a disease which shows a modification of the distribution and type of glycosaminoglycans produced in culture.

\section{ACKNOWLEDGMENTS}

We are grateful to Ms. Rasma Niedra for her technical assistance and to Dr. P. R. Laibson of Wills Eye Hospital, Philadelphia, Pa., and Dr. A. Boruchoff of Massachusetts Eye and Ear Infirmary, Boston, Mass., for keratoconus buttons.

This work was supported in part by research grant EY 01793 from the National Eye Institute and in part by the Medical Research Service of the Veterans Administration.

\section{REFERENCES}

1. Chi, H. H., H. M. Katzin, and C. C. Teng. 1956. Histopathology of keratoconus. Am. J. Ophthalmol. 42: 847860.

2. Teng, C. C. 1963. Electron microscope study of the pathology of keratoconus, part I. Am. J. Ophthalmol. 55: 18-47.

\footnotetext{
${ }^{2}$ Manuscript submitted for publication.
} 
3. Pataa, C., L. Joyon, and F. Roucher. 1970. Ultrastructure of keratoconus. Arch. Ophthalmol. 30: 403-417.

4. Stone, D. L., K. R. Kenyon, and W. J. Stark. 1976. Ultrastructure of keratoconus with healed hydrops. Am. J. Ophthalmol. 82: 450-458.

5. Anseth, A. 1969. Changes in the glycosaminoglycans in some human corneal disorders. Exp. Eye Res. 8: 438-441.

6. Praus, P., and G. N. Goldman. 1971. Glycosaminoglycans in human corneal buttons removed at keratoplasty. Ophthalmic. Res. 2: 223-230.

7. Robert, L., G. Schillinger, M. Moczar, S. Junqua, and E. Moczar. 1970. Biochemical study of the keratoconus. Arch. Ophthalmol. 30: 590-607.

8. Cannon, D. J., and C. S. Foster. 1978. Collagen crosslinking in keratoconus. Invest. Ophthalmol. 17: 63-65.

9. Dorfman, A., and R. Matalon. 1976. The mucopolysaccharidoses (a review). Proc. Natl. Acad. Sci. U. S. A. 73: 630-637.

10. Francois, J., V. Victoria-Troncoso, P. C. Maudgal, and P. Victoria-Ihler. 1976. Study of the lysosomes by vital stains in normal keratocytes and in keratocytes from macular dystrophy of the cornea. Invest. Ophthalmol. 15: 599605.

11. Klintworth, G. K., and C. F. Smith. 1977. Macular corneal dystrophy. Studies of sulfated glycosaminoglycans in corneal explant and confluent stromal cell cultures. Am. J. Pathol. 89: 167-182.

12. Yue, B. Y. J. T., J. L. Baum, and J. E. Silbert. 1978. Synthesis of glycosaminoglycans by cultures of normal human corneal endothelial and stromal cells. Invest. Ophthalmol. 17: 523-527.

13. McCarey, B. E., and M. E. Kaufman. 1974. Improved corneal storage. Invest. Ophthalmol. 13: 165-173.

14. Stocker, F. W., E. Eiring, R. Georgiade, and N. Georgiade.
1958. A tissue culture technique for growth of corneal epithelial, stromal and endothelial tissues separately. Am. J. Ophthalmol. 46: 294-298.

15. Perlman, M., J. L. Baum, and G. I. Kaye. 1974. Fine structure and collagen synthesis activity of monolayer cultures of rabbit corneal endothelium. J. Cell. Biol. 63: 306-311.

16. Yue, B. Y. J. T., J. L. Baum, and J. E. Silbert. 1976. The synthesis of glycosaminoglycans by cultures of rabbit corneal endothelial and stromal cells. Biochem. J. 158: $567-573$.

17. Udenfriend, S., S. Stein, P. Boehlen, W. Dairman, W. Leimgruber, and M. Weigele. 1972. Application of fluorescamine. A new reagent for assay of amino acids, peptides, proteins and other primary amines in picomole range. Science (Wash. D. C.). 178: 871-872.

18. Bitter, T., and H. M. Muir. 1962. A modified uronic acid carbazole reaction. Anal. Biochem. 4: 330-334.

19. Saito, H., T. Yamagata, and S. Suzuki. 1968. Formation of three types of disulfated disaccharides from chondroitin sulfates by chondroitinase digestion. J. Biol. Chem. 243: 1536-1542.

20. Kraemer, P. M. 1971. Heparan sulfates of cultured cells. I. Membrane-associated and cell-sap species in Chinese hamster cells. Biochemistry. 10: 1437-1445.

21. Kleinman, H. K., J. E. Silbert, and C. K. Silbert. 1975. Heparan sulfate of skin fibroblasts grown in culture. Connect. Tissue Res. 4: 17-23.

22. Buonassisi, V., and M. Root. 1975. Enzymatic degradation of heparin-related mucopolysaccharides from the surface of endothelial cell cultures. Biochim. Biophys. Acta. 385: $1-10$.

23. Conrad, G. W., and A. Dorfman. 1974. Synthesis of sulfated mucopolysaccharides by chick corneal fibroblasts in vitro. Exp. Eye Res. 18: 421-433. 